\title{
MEMOAR BURUH MIGRAN PEREMPUAN DAN MEDIA PERLAWANAN
}

\author{
Harjito \\ Universitas PGRI Semarang \\ Email:harjitoian@gmail.com
}

\begin{abstract}
ABSTRAK
Catatan perjalanan hidup seseorang yang terdapat dalam memoar memuat cara pandang seseorang atas peristiwa yang diceritakannnya. Memoar buruh migran perempuan mengungkapkan cara pemaknaan atas persoalan mereka. Tulisan ini bertujuan mengungkap struktur memoar dan penggunaannya sebagai media perlawanan buruh migran perempuan. Dalam menganalisis memoar, dipergunakan pendekatan sosiologi sastra. Bangunan strukur memoar terdiri dari empat pola tentang simbol sukses, naiknya status sosial, cara menghadapi dan cara memaknai penderitaan. Bangunan inimencerminkan upaya mereka dalam menghadapi penderitaan dan kesuksesan sebagai situasi sosial pengarangnya. Memoar membuka penafsiran yang berbeda atas makna hidup sukses bagi buruh migran. Memoar juga merupakan alternatif perlawanan bagi buruh migran perempuan dalam menghadapi problem sosial yang dihadapi yaitu menegasi kisah hidup sukses buruh migran yang tumbuh dan berkembang dalam budaya lisan.
\end{abstract}

Kata kunci: Buruh migran, narasi memoar, pengalaman perempuan 


\section{ABSTRACT}

The journey note of life of a person in the memoirs contains a person's perspective on the events she/he told. The memoirs ofwomen migrant workers reveals ways to interpret their problems. This paper aims to reveal the structure of memoirs and their use as a resistance media for women migrant workers. In analyzing the memoirs, the sociology of literature is used. The memoirs building structure consists of four patterns i.e. the symbol of success, the rising of social status, how to deal with and how to interpret suffering. This building reflects their efforts in dealing with suffering and success as the author's social situation. Memoirs open up different interpretations of the meaning of successful life for migrant workers. Memoir sare also an alternative to resistance for women migrant workers in dealing with social problems faced. Memoirs are an alternative to the resistance of women migrant workers. Memoirs are a living part of women migrant workers who seek to fight against the success stories of women migrant workers growing and developing in oral cultures.

Keywords: migrant workers, narrative memoirs, women's experiences

\section{A. Pendahuluan}

Buruh migran perempuan atau yang biasa disebut dengan tenaga kerja wanita adalah angkatan kerja wanita yang bekerja di luar negeri dalam kurun waktu tertentu dan menurut perjanjian kerja yang sudah disepakati (Purnamaningsih, 2011:14). Buruh migran perempuan tercatat telah ada sebelum Indonesia merdeka. Sejarah mencatat adanya buruh migran perempuan yang dikirim ke negeri Belanda. Disebutkan bahwa Pinah merupakan pembantu rumah tangga yang didatangkan dari Jawa. Ia hanya mendapat makanan roti kering, air dingin, dan mengenakan pakaian kebaya serta sarung yang dibawa dari kampung halaman (Mukthi, 2015).

Memoar merupakan suatu otobiografi mengenai bagian dari kehidupan individu. Otobiografi berbeda dengan biografi. 
Biografi adalah kisah kehidupan seseorang yang ditulis oleh orang lain. Penulis biografi merekonstruksi sejarah hidup individu lain dalam suatu pola tertentu yang bermakna. Sementara otobiografi mengandaikan subjeknya mandiri dalam merekonstruksi kehidupannya dalam suatu pola yang bermakna yang dilihatnya secara mandiri pula (Huen, 2000: 233). Hal mendasar dalam tulisan baik biografi maupun otobiografi adalah nama, tempat, dan tanggal lahir. Hal penting lainnya adalah peristiwa yang dianggap sebagai momentum bersejarah merupakan tonggak bagi seseorang dan dapat menginspirasi orang banyak serta berdampak bagi masyarakat (Nugraha, 2013: xvii-xviii).

Karena bagian dari kehidupan, memoar merupakan pengalaman hidup. Pengalaman bersifat pribadi, dinamis, bukan hanya berkaitan yang tindakan tetapi juga "yang bertindak". Artinya, terdapat subjek atau individu manusia yang melakukan suatu tindakan berkaitan dengan pengalaman hidupnya. Karena bersifat pribadi, seorang individu tidak akan memahami secara lengkap pengalaman individu lain. Di sisi lain, memoar tidak selalu lengkap menggambarkan pengalaman hidup seseorang di mana terkadang mereduksi pengalaman hidupnya karena keterbatasan kemampuan verbal dalam mengungkapkan diri (Santasombat, 2000: 127).

Terdapat tiga hal yang perlu diperhatikan dalam memoar. Satu, berisikan bagian kisah hidup seseorang. Dua, terdapat pola yang bermakna. Tiga, diperlukan ketrampilan verbal dalam menyusun memoar. Karena memoar ditulis oleh yang bersangkutan atau diri pribadi maka sang penulis dapat memilih mana hal-hal yang sekiranya patut disampaikan kepada orang lain atau menghilangkan hal-hal yang dianggap tidak perlu. Artinya, disadari atau tidak, penulis telah melakukan seleksi atas pengalamannya yang akan disampaikan kepada orang lain.

Memoar dapat disebut karya yang berkaitan dengan situasi sosial pengarangnya, dalam hal ini buruh migran perempuan. 
Memoar juga merupakan hasil pengaruh timbal balik dengan kondisi sosial budaya masyarakat. Terdapat dua hal mengapa tulisan ini penting. Satu, penelitian atas genre memoar belum banyak dilakukan. Dua, memoar buruh migran menyanggah gambaran dalam novel-novel modern Indonesia bahwa perlawanan perempuan biasanya dilakukan oleh perempuan dengan pendidikan tinggi dan kelas sosial tinggi.

Gender merupakan pembedaan-pembedaan yang bersifat konstruksi baik sosial maupun kultural yang dikenakan atas perbedaan dalam jenis kelamin (Fakih, 1996:8; Graddol \& Joan Swann, 1989: 10; Humm, 2007: 177). Feminisme dalam sastra setidaknya memiliki dua agenda penting. Satu pembongkaran dan pemaparan misogini dalam karya yang dihasilkan para pengarang. Dua, pemeriksaan dan promosi atas tulisan kaum perempuan yang selama ini terdominasi pengarang lelaki (Purbani, 2013: 367-368). Perempuan memiliki peran bukan hanya merawat anak-anak, suami, dan keluarga, tetapi juga menghidupi keluarga. Perempuan dikonstruksikan sebagai penopangekonomi yang memiliki penghasilan di dalamkeluarga. Meskipun memiliki penghasilan dan menopang ekonomi keluarga, perempuan dikonstruksi untuk mengabdi kepada suami dan anak-anak (Blackburn, 2009). Berkaitan dengan karya sastra, Budianta (1998: 50-52) menganalisis novel Lucy karya Jamaica Kincaih dan Jasmine karya Bharati Mukherjee. Novel tersebut mengisahkan tokoh utama seorang wanita dunia ketiga yang bekerja sebagai Tenaga Kerja Wanita di Amerika. Tenaga Kerja Wanita berada di persilangan antara masalah perempuan dan masalah penguasaan atas kaum tertindas.

Tulisan ini menggunakan pendekatan sosiologi sastra yang berpandangan bahwa karya sastra adalah hasil pengaruh timbal-balik dari faktor-faktor sosial dan kultural atau adanya hubungan sastra dan masyarakat (Damono, 2003: 3 ; Wellek dan Warren, 1990: 111). Swingewood dan Laurenson (1972: 
13-18) menyebut dua pendekatan dalam sosiologi sastra. Satu, sastra sebagai dokumentasi yang beranggapan bahwa sastra merupakan cerminan zaman. Dua, sastra berkaitan dengan produksi-produksi, dan terutama dengan situasi sosial pengarangnya.

Tulisan ini memilih tiga objek material sebagai bahan penelitian. Objek material pertama teks "Lima Kali menjadi Tenaga Kerja Wanita adalah Perjuanganku untuk Hidup Lebih Baik" ditulis oleh Dsh. Objek material kedua teks "Sukses adalah Impianku" ditulis oleh Eh. Objek material ketiga teks "Tidak Digaji, Dicaci, dan Disiksa: tapi Aku Disuruh Sabar, Aku Loncat dari Lantai 8", ditulis oleh Sri Lestari. Pemilihan atas teks-teks tersebut dengan beberapa pertimbangan. Satu, perempuan sebagai pelaku utama. Dua, subjek memiliki pengalaman menjadi buruh migran dengan negara yang berbeda, yaitu Arab Saudi, Hongkong, dan Singapura. Satu hal yang penting bahwa teks-teks tersebut memiliki tema yang sama berkaitan dengan buruh migran perempuan. Selain itu, meskipun berada atau bekerja di negara berbeda, terdapat jalinan persoalan yang sama yang dialami oleh buruh migran perempuan.

Tulisan ini menganalisis bagaimana memoar sebagai media perlawanan buruh migran dengan cara memaparkan struktur memoar yang ditulis buruh migran perempuan dan wujud perlawanan buruh migran perempuan dalam dalam memoar.

\section{B. Pembahasan}

\section{Struktur Memoar}

Struktur memoar dibangun atas dua unsur, yaitu narasi dan peta perjalanan. Disebut narasi karena terdapat alur peristiwa dengan subjek utama sang penulis. Sang penulis dalam hal ini perempuan yang bekerja sebagai buruh migran menuliskan sebagian kisah hidup yang berkaitan dengan pengalamannya sebagai buruh migran. Selain berupa narasi, para penulis juga 
membuat peta perjalanan dari rumah ke negara yang dituju. Dengan demikian, memoar berisi narasi dan dapat ditambah peta perjalanan. Disebut "dan dapat ditambah" karena tidak semua tulisan menyertakan peta perjalanan.

Narasi buruh migran perempuan dibangun dalam empat pola. Satu, naiknya kelas sosial dengan kepemilikan benda atau barang. Kelas sosial tidak hanya mengacu pada kepemilikan modal ekonomi, tetapi juga tentang banyak praktik kelas yang meliputi selera makan, cara berpakaian, disposisi tubuh, model rumah, dan beragam pilihan sosial dalam kehidupan sehari-hari (Wilkes, 2005: 139). Dua, menyembunyikan penderitaan dan kesengsaraan selama menjadi buruh migran. Tiga, manakala mengalami penderitaan, hal tersebut dianggap sebagai ujian dan konsekuensi dalam meraih hidup sukses. Empat, munculnya simbol-simbol atas kesuksesan.

Kisah hidup sukses didengar dan dilihat oleh EH dan Sri Lestari. Dalam SI dituliskan bahwa EH melihat kakaknya hidup sukses setelah pulang dari Hongkong. Sukses yang dimaksud adalah kakaknya dapat memiliki sawah dan motor yang selama ini hanya menjadi impian. "Setelah kakak saya pulang dari Hong Kong, saya ingin seperti kakak yang bisa punya sawah, motor dan lain-lain setelah bekerja di luar negeri" (Eh, tt: 68). Kepemilikan atas benda atau barang seperti sawah atau motor ditunjukkan melalui kemampuan membeli. Seseorang dapat membeli sesuatu manakala memiliki uang dan uang tersebut diperoleh melalui bekerja menjadi buruh migran. Dari frasa "bisa punya sawah" mengindikasikan bahwa selama ini mereka tidak memiliki sawah. Mereka adalah petani penggarap, petani yang mengerjakan sawah milik orang lain, bukan petani yang mengerjakan sawah miliknya pribadi.

Sang kakak berkata bahwa hidup Eh tidak akan pernah berubah kalau hanya tinggal di desa. Artinya, perubahan pada kehidupan yang lebih baik hanya mungkin ketika individu 
memiliki kemampuan untuk ke luar dari desa. Dua hal tersebut yang mendorong Eh berniat menjadi buruh migran. Hal yang sama terjadi pada Sri Lestari. Dalam teks "Tidak Digaji, Dicaci, dan Disiksa: tapi Aku Disuruh Sabar, Aku Loncat dari Lantai 8", dikisahkan bahwa Sri Lestari tertarik bekerja sebagai buruh migran karena melihat tetangga sekampungnya yang sukses setelah bekerja sebagai buruh migran seperti kutipan berikut. "Pertama kali ku tertarik bekerja ke luar negeri karena melihat orang sekampungku yang pada sukses kemudian saya tertarik dan lalu saya ikut-ikutan bekerja ke Luar Negeri" (Lestari, tt: 94).

Sukses menjadi sebuah mantra sakti yang tidak bisa dijauhkan dari kehidupan sehari-hari. Sukses dapat dimaknai sebagai standar hidup atau dengan kata yang lebih eksplisit bermakna kekayaan / berlimpahnya aspek material. Sukses menjadi impian sekaligus tujuan hidup, termasuk bagi buruh migran perempuan. Hal ini terlihat dalam judul "Sukses adalah Impianku". Dengan kisah hidup sukses, masyarakat terdorong untuk mengikuti jejak. Kisah hidup sukses seseorang bergaung melalui mendengar dan melihat. Pengertian mendengar dapat berupa hanya mendengar narasi dari mulut ke mulut dalam perbincangan lisan. Pengertian melihat berwujud individu melihat secara langsung bagaimana kesuksesan seseorang. Yang paling menarik apabila individu melihat sekaligus bertemu dengan seseorang yang dianggap sukses. Apalagi seseorang tersebut berasal dari lingkungan terdekat. Dalam istilah Ong (tt: 19), budaya lisan menghasilkan performa verbal yang kuat dan indah. Karena itu, individu yang mendengar dan melihatnya menjadi tertarik dan terpengaruh.

Salah satu alasan mengapa seseorang memilih menjadi buruh migran perempuan adalah terpengaruh oleh kisah tetangga atau teman dekat yang sudah sukses menjadi buruh migran perempuan (Santoss, 2010: 2). Kisah hidup sukses bukan hanya menarik, tetapi juga mempengaruhi Eh, Lestari, dan para 
perempuan yang pada awalnya hanya mengikut para pendahulu yang dianggap sukses. Narasi kesuksesan tidak saja didengar secara lisan tetapi juga dapat dilihat secara langsung karena terjadi dan berada di lingkungan sekitar sehingga mereka dapat mengecek kebenaran atau kebohongannya.

Bagi Dsh, memaknai sukses dengan istilah "hidup lebih baik". Dsh menjadi buruh migran karena menginginkan hidup yang lebih baik (Dsh, tt: 22). Dsh, Lestari, dan Eh termasuk dalam golongan keluarga dengan penghasilan rendah. Pada saat berangkat, Dsh masih berumur 15 tahun. Karena itu, pada wawancara berikutnya umurnya dituakan menjadi 25 tahun. Bahkan Dsh lima kali berangkat menjadi buruh migran jika hanya tinggal di desa, ia tidak dapat berbuat banyak untuk meningkatkan taraf kehidupannya. Pada saat menjadi buruh migran pertama kali di Arab Saudi, Dsh belum berkeluarga dan berpendidikan tamat Sekolah Dasar. Sri Lestari pada saat bekerja di Singapura baru saja lulus Sekolah Menengah Pertama dan belum berkeluarga. Sementara itu, Umur Eh lebih tinggi dari Dsh, 19 tahun dengan pendidikan Sekolah Menengah Pertama dan pada saat bekerja di Hongkong, ia sudah bersuami.

Berdasarkan data-data tersebut, para buruh migran perempuan memiliki latar belakang pendidikan yang rendah dengan umur yang masih sangat muda di bawah 20 tahun. Mereka memiliki niat yang sangat kuat untuk menaikkan kelas sosial. Kesadaran menaikkan kelas sosial ini tidak akan dapat terwujud manakala mereka tetap berada di desa yang tidak mampu menyediakan lapangan pekerjaan selain bertani. Eh, Dsh, dan Sri Lestari berasal dari keluarga petani. Desa juga dianggap sebagai tempat yang statis dan tidak cepat berkembang.

Data tersebut sejalan dengan temuan bahwa keputusan buruh migran perempuan berangkat ke luar negeri dikarenakan kurangnya lapangan pekerjaan, kemiskinan, pendidikan rendah, dan ketrampilan yang rendah (Kumalasari, 2011: 108 ; Subadi, 
2010: 165). Selain itu, tingkat pendidikan, jumlah tanggungan keluarga, dan pendapatan keluarga memiliki hubungan dengan lama mereka bekerja di luar negeri (Purnamaningsih, 2011: 25).

Apa yang disajikan dalam memoar buruh migran sangat berbeda dengan gambaran sosial tokoh perempuan yang terdapat dalam novel Indonesia. Novel-novel Indonesia modern dominan menggambarkan perempuan perkotaan yang terpelajar, terdidik, berkemampuan ekonomi cukup, dan berpenghasilan cukup (Saryono, 2009: 19). Memoar buruh perempuan juga menyanggah gambaran atas novel Indonesia periode 1900-2000, bahwa hanya perempuan yang berlatar belakang sosial tinggi, berpendidikan, serta berkarakter yang memiliki kemampuan melakukan perlawanan (Liliani dan Esti Swatika Sari, 2010: 50).

Dalam memoar, terdapat hal-hal yang tidak disampaikan atau disembunyikan agar pendengar tetap tertarik dan dapat dipengaruhi. Hal inilah yang pada gilirannya akan dirasakan dan dialami oleh para buruh migran. Narasi yang disembunyikan adalah penderitaan dan kesengsaraan ketika berada di negeri yang berbeda secara bahasa dan budaya.

Penderitaan buruh migran dapat diperhatikan dari pengakuan Dsh pada kutipan, “Ternyata menjadi TK itu sangat susah, apalagi pas pertama kali ke sana musim dingin, aku sangat kedinginan sampai-sampai menangis “ (Dsh, tt: 22). Kata "ternyata" membuktikan adanya kesadaran yang baru ditemukan, sebuah kesadaran yang berbeda atas pemahaman sebelumnya. Dsh bekerja di sebuah keluarga dengan lima anak yang bandel dan Dsh seorang perempuan yang masih belum berkeluarga sehingga tidak pernah dapat tidur nyenyak karena pernah dirayu untuk menuruti nafsu birahi majikan lelaki. Bahkan, Dsh menyiapkan pisau di bawah bantalnya untuk berjaga-jaga. Dsh juga mengalami perlakuan kasar dari majikan yang menyebabkan dia kabur (Dsh, tt: 24). Salah satu penyebab terjadinya kekerasan pada perempuan adalah kelemahan struktur fisiologis yang 
dimiliki oleh perempuan dan dimanfaatkan oleh para pelaku kekerasan (Werdiningsih, 2016: 102).

Sesudah menikah dan memiliki anak berumur satu bulan, Dsh berangkat kembali ke Arab Saudi. Padahal, bayinya masih membutuhkan air susu ibu. Ketika pulang, sang anak tidak mengenal siapa ibunya. Sebuah penderitaan dan kesedihan yang jarang diungkap. Eh dilarang untuk sering menerima surat, termasuk tidak memberikan alamat ke teman-temannya. Ia pernah kehilangan uang titipan dari kakak dan karena itu terpaksa ia juga harus menggantinya. Pada akhirnya, penderitaan, kesedihan, dan siksaan ditutupi dan ditepis dengan keyakinan bahwa kesemuanya merupakan "suatu ujian untuk mencapai sukses", sebagaimana yang ditulis oleh Dsh (tt: 23).

Peta perjalanan berisi gambar sederhana tempat-tempat penting yang dikunjungi mulai dari rumah sampai negara tempat tujuan. Dsh misalnya menyebutkan rumah, Jakarta, dan Arab Saudi. Eh menyebut rumah, bandara Solo, Singapura, Hongkong, Jakarta, dan Semarang. Gambar peta perjalanan dibuat dengan tulisan tangan.

Peta perjalanan memiliki beberapa fungsi. Satu, memeriksa apakah buruh migran yang telah menulis memang benar-benar memiliki pengalamanan seperti yang dituliskan. Dua, memeriksa apakah buruh migran memiliki ingatan yang memadai atas tempat-tempat termasuk peristiwa-peristiwa yang pernah dialami. Tiga, menyederhanakan sekaligus sebagai panduan pada saat buruh migran perempuan menulis.

Apa yang telah dibahas dapat diperhatikan dalam Tabel 1.

Tabel 1 Buruh Migran Perempuan

\begin{tabular}{llll}
\hline & Dsh & Eh & Sri Lestari \\
Usia & 15 & 19 & Di bawah 20 \\
Pendidikan & SD & SMP & SMP \\
Keluarga & petani & petani & Petani \\
Sumber kisah & - & kakak & Orang sekampung \\
Tempat bekerja & Arab Saudi & Hongkong & Singapura \\
\hline
\end{tabular}




\section{Memoar: Suara Perempuan dan Media Perlawanan}

Kekuasaan selalu melekat pada kelompok atau sesorang. Kekuasaan dapat dipahami sebagai kemampuan subjek manusia untuk menetapkan alternatif bertindak atau alternatif memilih (Budiarjo, 1991: 9-43). Foucault mempelajari keterkaitan antara kekuasaan dan pengetahuan. Foucault juga memperhatikan pengetahuan yang diabaikan, lokal, atau remeh temeh (Sarup, 1989, 63-95). Bagi Foucault (2000: 115-117), kekuasaan tak terhitung jumlahnya dan selama ada kekuasaan selalu ada perlawanan. Perlawanan atau resistensi pada kekuasaan dapat berwujud mengambil bentuk wacana baru untuk menghasilkan "kebenaran baru" yang merupakan wacana tanding atau wacana yang dibalikkan dalam melawan kebenaran yang selama ini dianggap dominan (Brooks, tt: 93-94).

Media dapat dipahami sebagai segala bentuk dan saluran yang dipergunakan untuk menyampaikan informasi atau pesan sehingga manusia mendapatkan pengetahuan, ketrampilan, atau sikap. Yang termasuk media yaitu, televisi, film, foto, radio, rekaman audio, gambar, bahan cetakan dan sejenisnya. Termasuk dalam hal ini buku (Arsyad, 1997: 3-4). Buku merupakan lembaran kertas yang berisi tulisan (Pusat Bahasa Departemen Pendidikan Nasional, 2008: 229). Batu merupakan media tertua untuk menulis. Sesudah itu dikenal lembaranlembaran lempung, papirus, kertas kulit, kulit tumbuhan, dan berikutnya adalah kertas modern (Mukthi, 2010).

Buku Ketika Perempuan Bertutur: Kumpulan Pengalaman Buruh Migran memiliki 113 halaman berisi enam belas memoar yang ditulis oleh enam belas perempuan yang bekerja di luar negeri, dengan pengelompokkan negara, yaitu Malaysia, Arab Saudi, Hongkong, Taiwan, dan Singapura. Dengan ukuran buku $23 \times 21 \mathrm{~cm}$, masing-masing memoar antara 2-7 halaman berupa narasi. Beberapa penulis menyebutkan nama asli seperti Sri Lestari, tetapi beberapa lainnya hanya menyebutkan inisial. 
Selain narasi, disertakan juga peta perjalanan. Karena ditulis oleh perempuan, memoar yang terdapat dapat buku tersebut dapat disebut sebagai suara yang disampaikan oleh perempuan.

Teks "Lima Kali menjadi TKW adalah Perjuanganku untuk Hidup Lebih Baik" ditulis oleh Dsh sepanjang 5 halaman. Suaminya seorang petani dan mereka memiliki 2 anak. Sampai sekarang pun Dsh masih bekerja keras untuk menghidupi keluarga. Selain mengurus anak dan suami, Dsh berjualan sayur-mayur berkeliling kampung menggunakan sepeda. SI ditulis oleh Eh sepanjang 4 halaman. Selain menjaga anak, EH melakukan bertani di sawah. Sejalan dengan hal tersebut, mantan buruh migran perempuan yang tinggal di Kecamatan Sempu Banyuwangi belajar decoupage di Balai Desa Temuguruh. Mereka belajar menggunting pola bunga di kertas dan menempelkannya ke dompet atau tas. Decoupage merupakan seni menghias media atau benda dengan cara menempelkan kertas pada permukaan benda. Pelatihan decoupage kepada mantan buruh migran perempuan tersebut dengan tujuan agar mereka dapat mencukupi kebutuhan seharihari dan tidak kembali bekerja ke luar negeri. (http:/ / regional. kompas.com/read/2017/04/25/13430551/di.banyuwangi. mantan.tkw.belajar.decoupage).

Sesudah berada di desa kembali, Lestari bekerja serabutan dan sepanjang 6,5 halaman ia menceritakan pengalaman yang banyak mengalami siksaan. Ketika sampai di tanah air, Lestari (tt: 99) merasakan kebahagiaan luar biasa karena dapat menghirup udara kebebasan yang dilukiskannya dengan "merasa bebas seperti baru keluar dari penjara", meskipun ia tidak membawa uang. Lestari menerima siksaan fisik, dicaci, bahkan dikurung sampai dua hari (Lestari, tt: 98).

Musibah sering dialami oleh buruh migran. Zudi Prasetyo yang berumur 28 tahun, seorang buruh migran yang berasal dari Dusun Goledok, Desa Sindurejo, Kecamatan Toroh, Kabupaten 
Grobogan, Jawa Tengah, mengalami kecelakaan kerja di Taiwan hingga kaki kanannya harus diamputasi (http:/ / regional.kompas. com/read/2017/05/05/06300081/cerita.tki.harus. diamputasi. kakinya.karena.terlindas.mesin.di.taiwan). Kecelakaan yang mengakibatkan hilangnya nyawa juga menimpa buruh migran. Yefta Setiawan yang berumur 20 tahun dan berasal dari Dusun Citromenggala, Desa Ngawen, Kecamatan Muntilan, Kabupaten Magelang, Jawa Tengah, meninggal dunia akibat kecelakaan kerja di Jepang (http://regional.kompas.com/read/2017/ 04/ 28/20570051/tertimpa.mesin.saat.bekerja.tki.asal.magelang. meninggal.di.jepang). Dalam rentang waktu empat bulan sejak Januari hingga April 2017, sebanyak 28 buruh migran yang berasal dari Nusa Tenggara Timur(NTT) meninggal di Malaysia. Sebanyak 27 orang dari mereka merupakan buruh migran ilegal atau tidak memiliki dokumen resmi saat masuk dan bekerja di Malaysia (http:/ / regional.kompas.com/read/2017/04/25/19315601/4. bulan. 28.tki.asal.ntt. meninggal.di.malaysia.).

Dengan rasa trauma yang dirasakan, Dsh memberikan pesan bahwa menjadi buruh migran bukanlah pekerjaan yang ringan. Dsh mengalami beberapa kali perlakuan kasar oleh majikan. Eh juga menggambarkan bahwa menjadi buruh migran bukan pekerjaan yang nyaman. Hal ini tampak jelas dari judul yang mengindikasikan penderitaan yang dialami, yaitu "Tidak Digaji, Dicaci, dan Disiksa: tapi Aku Disuruh Sabar, Aku Loncat dari Lantai 8"

Dalam teks tersebut tampak jelas kesadaran Lestari dalam menyampaikan memoar sejak dari awal paragraf pertama sebagai berikut :

Pertama-tama saya menyampaikan puji syukur kepada Tuhan yang Mahas Esa karena sampai detik ini aku mash diberi perlindungan sehingga aku masih bisa menceritakan pengalaman aku, dan Insya-Allah saya akan menceritakan dengan benar dan seksama sehingga yang membaca buku ini juga ikut sedih atau iba hati. (Lestari, tt: 94) 
Kutipan tersebut mengandung tiga hal. Satu, pengaruh memberi sambutan dengan munculnya kata "pertama-tama". Hal ini dapat terjadi karena dalam kehidupan di masyarakat, Lestari pernah melihat atau mendengar orang lain yang sedang memberi sambutan dalam suatu acara. Dua, religiusitas pada diri Lestari yang menyebut rasa syukur kepada Tuhan. Rasa syukur juga mengindikasikan sekaligus menjelaskan tradisi sambutan seperti yang telah disampaikan. Tiga, frasa "bisa menceritakan pengalaman" mengindikasikan bahwa penulis dalam hal ini Lestari dengan sengaja hendak menyampaikan sesuatu kepada pembaca. Artinya, menceritakan itu bukanlah tindakan yang tidak disadari oleh penulis. Empat, berkaitan dengan isi, apa yang disampaikan penulis merupakan suatu yang benar terjadi karena merupakan pengalaman penulis. Lima, frasa "diberi perlindungan" mengindikasikan terdapat suatu penderitaan yang berat yang pernah dialamai oleh penulis. Hal ini ditunjukkan dengan berbagai peristiwa yang memang dialami penulis selama menjadi buruh migran.Lestari secara jelas menyampaikan pesannya kepada pembaca.

Begitulah kisahku selama bekerja di luar Negeri untuk menjadi TKW semogayang baca tulisan ini tidakmengantuk, dan dapat mengambil pelajaran dari pengalaman ini dan kalau seandainya diantara para pembaca ada yang berniat menjadi TKW, semoga tidak menglami pengalaman yang pahit seperti saya. Amin. (Lestari, tt: 100).

Kekuatan tulisan Lestari pada keterbukaannya untuk tidak memaksa pembaca menerima pandangan-pandangannya. Dengan rendah hati, Lestari berharap semoga mereka yang membaca memoarnya tidak mengantuk.

Baik Dsh maupun Eh memiliki persamaan dalam hal penggunaan bahasa yang lugas bahwa tujuan hidup mereka adalah kesuksesan. Dsh menggunakan istilah "hidup lebih baik" yang dinyatakan dalam judul memoar. Eh menggunakan istilah 
"sukses" yang juga dinyatakan dalam judul. Untuk menjadi TKW tidak mudah karena banyak perbedaan antara buruh migran dengan majikan. Dsh masih ingin menjadi buruh migran, tetapi ia masih trauma dengan pengalaman dan ketakutannya mendapat majikan yang jahat.

Dalam novel-novel tahun 2000an yang ditulis oleh pengarang perempuan, salah satu tema yang dominan adalah perlawanan perempuan atas dominasi patriarki dan kekerasan yang menimpa atas diri perempuan (Wiyatmi, 2012: 51). Dalam Pengantar buku Ketika Perempuan Bertutur: Kumpulan Pengalaman Buruh Migran (tt: iv) disebutkan bahwa pengalaman perempuan belum dianggap sebagai sumber ilmu dan pengetahuan. Selain sebagai sumber ilmu pengetahuan, pengalaman perempuan yang diwujudkan dalam bentuk buku dimaksudkan untuk menumbuhkan kepercayaan diri para perempuan terutama buruh migran. Dengan menyampaikan cerita, para buruh migran perempuan telah membantu perempuan lain pengalaman bekerja di luar negeri baik yang selama ini hendak menjadi buruh migran maupun yang tidak. Dalam bahasa lain, memoar buruh migran merupakan suara perempuan yang berisi perlawanan atas kondisi sosial para buruh migran.

\section{Narasi Kesuksesan dalam Memoar}

Narasi kesuksesan harus ditunjukkan kepada masyarakat melalui simbol-simbol kepemilikan barang atau hasil bekerja selama menjadi buruh migran. Dsh menggunakannya untuk membeli motor, kebun, sawah, dan memperbaiki rumah. EH membelanjakan hasil kerjanya untuk membeli motor, traktor, kebun, sawah, dan memperbaiki rumah. Dalam Serat Wulang Putri yang ditulis khusus untuk panduan tingkah laku bagi perempuan Jawa di masa keraton Surakarta, disebutkan bahwa seorang perempuan yang utama akan 
mendapatkan keberuntungan manakala memiliki perilaku seperti belajar ilmu pengetahuan, ketrampilan, pemberani, dan kekayaan (Widyastuti, 2014: 115, 126). Pernyataan tersebut mengindikasikan pandangan masyarakat atas perempuan didasarkan atas kekayaan sebagai salah satu kepemilikan.

Pilihan membelanjakan perolehan sebagai buruh migran, dapat dikelompokkan menjadi empat, yaitu: rumah, sawah, kebun, dan motor yang masing-masing memiliki makna yang berbeda. Secara umum buruh migran perempuan berasal dari tradisi agraris atau petani. Dalam tradisi Jawa, seorang lelaki disebut sempurna dengan lima kepemilikan, yaitu rumah, senjata, kendaraan, istri, dan burung (Raap, 2015b: 147). Dengan tolok ukur itu, Dsh dan Eh membelajakan pendapatannya. Secara umum, pada masa dahulu rumah dihuni satu keluarga, dengan struktur utama kayu dan bambu terdiri atas bagian depan, dalam, dan belakang. Di masa kini, masyarakat lebih menyukai membangun rumah dengan struktur tembok (Raap, 2015a: 140-141). Jatman (1994: 141, 413). dalam puisi berjudul "Omah" menyebutkan bahwa rumah merupakan tempat pertemuan lelaki dan istrinya. Rumah juga merupakan rasa "kasih bertempat tinggal"

Jika seseorang sudah memiliki rumah, persoalan berikutnya adalah menjadikannya semakin kokoh, kuat, dan indah. Dengan memperbaiki rumah, bukan hanya nyaman ditempati tetapi juga menunjukkan kelas sosial. Kemampuan memperbaiki rumah dijadikan sebagai simbol kesuksesan seorang buruh migran perempuan.

Dsh dan Eh berasal dari keluarga petani. Dalam mengerjakan sawah, biasanya petani menggunakan empat pasang kerbau. Kerbau dipergunakan karena dapat bergerak lebih lincah di lumpur dari pada sapi atau kuda (Raap, 2013: 145). Sawah menjadi kebutuhan utama dalam kehidupan seorang petani. Sawah adalah nyawa bagi mati atau hidupnya petani. 
Dengan membeli sawah, Dsh dan Eh masih melanjutkan tradisi agraris, bukan sebagai penggarap tetapi sebagai pemilik. Pada zaman yang lebih modern, pengganti kerbau adalah traktor. Eh mengerjakan sawah dengan cara yang lebih modern. Oleh Dsh dan Eh, modernitas tidak dilawan atau ditolak, tetapi diakrabi dan dimanfaatkan. Di sini, pranata modern ditandai dengan kehadiran motor dan traktor.

Dalam keluarga petani, sawah dipergunakan untuk menanam padi sebagai penghasil beras yang merupakan bahan makanan pokok. Kebun dipergunakan untuk menanam pohon atau sayur-sayuran yang dapat membantu kebutuhan sehari-hari. Selain itu, kebun juga dapat dimanfaatkan untuk tanaman kesehatan. Artinya, dengan kepemilikan kebun, petani dapat mandiri untuk tidak terlalu banyak membelanjakan penghasilannya.

Motor merupakan salah satu jenis kendaraan. Dengan kepemilikan kendaraan, aktifitas Dsh dan Eh dapat lebih cepat dan menjangkau tempat-tempat yang lebih jauh. Mobilitas Dsh dan Eh dapat lebih dinamis. Dalam satu sisi, mereka dapat bergerak lebih cepat, di sisi yang lain mereka harus tunduk pada sikus waktu agraris dalam menanam, mengolah, dan memanen padi di sawah sebagaimana dalam tabel 2

Seperti yang telah disampaikan di awal tulisan, memoar berkaitan dengan pola yang bermakna dalam bagian kehidupan individu. Dalam memoar buruh migran perempuan, terjadi pergeseran dalam memaknai kehidupan. Ada dua penyebab pergerseran pemaknaan atas hidup, yaitu umur dan anak. Jika pada usia yang masih belia, para buruh migran memaknai hidup sukses dengan indikator kepemilikan atas sekian barang dan benda. Pada saat kini, ketika usia telah bertambah, buruh migran perempuan justru dapat lebih menerima diri atau dalam bahasa Jawa nrimo. Hal ini dapat diperhatikan pada kenyataan bahwa mereka kini bekerja sebagai penjual sayur, bertani, atau serabutan. 
Berkaitan dengan pekerjaan tersebut, terdapat hal yang menarik dari pandangan perempuan yang hidup di daerah pedesaan di wilayah Pati dan Jepara, Jawa Tengah, pada saat suami bekerja merantau. Ditemukan bahwa para perempuan berusaha bekerja apa saja untuk mendapatkan uang, tetapi apabila tidak dapat bekerja mereka berusaha menjadi ibu rumah tangga yang baik meskipun merasa jenuh (Miftahurrohmah, 2015: 136). Artinya, bekerja memperoleh penghasilan dapat dianggap penting, tetapi yang juga penting adalah menjadi istri yang baik.

Tabel 2. Simbol Sukses Perempuan Buruh Migran

\begin{tabular}{llll}
\hline & Dsh & Eh & Sri Lestari \\
\hline $\begin{array}{l}\text { Distribusi } \\
\text { hasil } \\
\text { sebagai } \\
\text { buruh } \\
\text { migran }\end{array}$ & $\begin{array}{l}\text { Membeli motor, } \\
\text { kebun, sawah; } \\
\text { memperbaiki rumah }\end{array}$ & $\begin{array}{l}\text { Membeli motor, } \\
\text { kebun, sawah, } \\
\text { traktor; memperbaiki } \\
\text { rumah }\end{array}$ & - \\
$\begin{array}{l}\text { Pilihan } \\
\text { Ekonomi }\end{array}$ & Jual sayur & Bertani & Serabutan \\
$\begin{array}{l}\text { Saat ini } \\
\text { Pesan }\end{array}$ & $\begin{array}{l}\text { Sangat susah } \\
\text { menjadi buruh } \\
\text { migran }\end{array}$ & $\begin{array}{l}\text { Belajar disiplin dari } \\
\text { majikan }\end{array}$ & $\begin{array}{l}\text { Pembaca tidak } \\
\text { mengalami kesengsaraan } \\
\text { sebagai buruh migran }\end{array}$ \\
\hline
\end{tabular}

Eh (tt: 70) dengan jelas menyebutkan bahwa hari-harinya disi dengan menjaga anak yang baru berumur 4,5 tahun. Hal ini sejalan dengan hasil temuan Harjito (2016) bahwa bagi perempuan Jawa, anak merupakan kebahagiaan dan karunia dari Tuhan yang sangat berharga. Karenanya, memiliki anak bukan hanya bermakna sosial ekonomis, tetapi juga religius. Dibutuhkan usaha dan kesabaran untuk dapat mempunyai anak. Bahkan, demi anak, perempuan memiliki kemandirian untuk memelihara dan menghidupi anak (Harjito, 2014). Perempuan juga menjadi pelindung keluarga dengan berusaha menjaga keutuhan rumah tangga melalui sifat sabar dan setia (Harjito, 2017). Pada akhirnya, para perempuan buruh migran kembali 
menjadi petani tetapi dengan kelas sosial yang berbeda. Kini buruh migran perempuan mengerjakan sawah miliknya, bukan sawah milik orang lain.

\section{Simpulan}

Buruh migran perempuan secara umum berasal dari keluarga petani dan bekerja di luar negeri dengan keinginan tunggal hidup menjadi sukses. Tolok ukur hidup sukses adalah kepemilikan atas barang atau benda seperti rumah, sawah, dan kendaraan. Ketika kepemilikan atas rumah, sawah, dan kendaraan telah terpenuhi, mereka tidak lagi berkeinginan bekerja ke luar negeri. Hal ini dikarenakan dua faktor, yaitu usia yang bertambah dan kehadiran anak yang menjadikan mereka lebih dewasa dan matang dalam memaknai pengertian hidup sukses.

Struktur memoar tersusun atas dua unsur, yaitu narasi dan peta perjalanan. Narasi buruh migran dibangun dalam empat pola. Satu, naiknya kelas sosial dengan kepemilikan benda atau barang. Dua, menyembunyikan penderitaan dan kesengsaraan selama menjadi buruh migran. Tiga, manakala mengalami penderitaan, hal tersebut dianggap sebagai ujian dan konsekuensi dalam meraih hidup sukses. Empat, terdapat simbol hidup sukses. Peta perjalanan memiliki fungsi untuk memeriksa apakah subjek penulis benar-benar sebagai buruh migran dan memiliki daya ingat pada tempat-tempat yang telah dikunjungi. Memoar membuka penafsiran yang berbeda atas makna hidup sukses yang selama ini diimpikan masyarakat terutama para buruh migran. Memoar merupakan alternatif perlawanan bagi buruh migran perempuan yaitu memberikan wacana tandingan yaitu upaya perlawanan untuk menegasi kisah hidup sukses yang tumbuh dan berkembang dalam budaya lisan. 


\section{Daftar Pustaka}

Arsyad, Ashar, 1997, Media Pembelajaran. Jakarta: PT Raja Grafindo Persada.

Blackburn, Susan, 2009, Perempuan dan Negara dalam Era Indonesia Modern. Terjemahan Estom Aritonang. Jakarta: Kalyanamitra.

Brooks, Ann, Tt. Posfeminisme \& Cultural Studies Sebuah Pengantar Paling Komprehensif. Terjemahan S Kunto Adi Wibowo. Yogyakarta: Jalasutra.

Budiardjo, Miriam, 1991, “Konsep Kekuasaan: Tinjauan Kepustakaan" dalam Budiardjo. Aneka Pemikiran tentang Kuasa dan Wibawa. Jakarta: Pustaka Sinar Harapan.

Budianta, Melani, 1998, "Pena yang Berdarah: TKW dalam Novel Postkolonial:" . Dalam Kalam. 11 hlm. 51-67

Damono, Sapardi Djoko, 2003, Sosiologi Sastra. Semarang: Magister Ilmu Susastra Program Pascasarjana Universitas Diponegoro.

Dsh., Tt, "Lima Kali menjadi TKW adalah Perjuanganku untuk Hidup Lebih Baik". Dalam Ketika Perempuan Bertutur: Kumpulan Pengalaman Buruh Migran Perempuan. Salma Safitri Rahayaan (editor). Semaran: LRCKCHAM

Eh, Tt, "Sukses adalah Impianku". dalam Ketika Perempuan Bertutur: Kumpulan Pengalaman Buruh Migran Perempuan. Salma Safitri Rahayaan (editor). Semarang: LRC-KCHAM

Fakih, Mansour, 1996, Analisis Gender dan Transformasi Sosial. Yogyakarta: PustakaPelajar.

Foucault, Michel, 2000, Seks E Kekuasaan: Sejarah Seksualitas. Terjemahan Rahayu S Hidayat. Jakarta: Gramedia.

Graddol, David dan Joan Swann, 1989. Gender Voices, Telaah Kritis Relasi Bahasa-Jender. Terjemahan M Muhith. Pasuruan: Pedati. 
Jatman, Darmanto, 1994, “Omah". dalam Golf untuk Rakyat. Yogyakarta: Bentang.

Harjito, 2014, “Kemandirian Perempuan Jawa dalam Cerita Tradisional", dalam Litera, Jurnal Penelitan Bahasa, Sastra, dan Pengajaraannya. Vol. 13, No. 2, Oktober, hlm.201-214.

2016, "The Relationship Between Javanese Women and Their Daughter in Indonesia Literature" dalam The Social Sciences. Vol 11. Issue 27 hlm. 6497-6503.

2017, "Supernatural Women Modernity in Indonesian Literature" dalam Asian Social Science, Volume 13, No 10, Oktober 2017, hlm 65-74.

http://regional.kompas.com/read/2017/04/25/13430551/ di.banyuwangi.mantan.tkw.belajar.decoupage. Diakses 30 Mei 2017.

http://regional.kompas.com/read/2017/04/25/19315601/4.bulan.28. tki.asal.ntt.meninggal.di.malaysia. Diakses 30 Mei 2017.

http://regional.kompas.com/read/2017/04/28/20570051/tertimpa. mesin.saat.bekerja.tki.asal.magelang.meninggal.di.jepang. Diakses 30 Mei 2017.

http://regional.kompas.com/read/2017/05/05/06300081/cerita. tki.harus.diamputasi.kakinya.karena.terlindas.mesin. di.taiwan. Diakses 30 Mei 2017.

Huem, P Lim Pui. 2000. “Rekonstruksi Sejarah Pengalaman Hidup" dalam Sejarah Lisan di Asia Tenggara: Teori dan Metode. Jakarta: LP3ES

Humm, Maggie, 2007, Ensiklopedia Feminisme. Terjemahan Mundi Rahayu. Yogyakarta: Fajar Pustaka Baru.

Kumalasari, Luluk Dwi, 2011, "Keharmonisan Keluarga TKW dalam Perspektif Gender (Studi di Donomulyo Malang)". Dalam Humanity. 6 (2) hlm. 106-115.

Lestari, Sri, Tt, "Tidak Digaji, Dicaci, dan Disiksa tapi Aku Disuruh Sabar, Aku Loncat dari Lantai “. Dalam Ketika Perempuan Bertutur: Kumpulan Pengalaman Buruh 
Migran Perempuan. Salma Safitri Rahayaan (editor). Semarang: LRC-KCHAM.

Liliani, Else dan Esti Swatika Sari, 2010, "Refleksi Peran Perempuan dalam Novel Indonesia 1900-2000", dalam Litera, Jurnal Penelitan Bahasa, Sastra, dan Pengajaraannya. Vol. 9, No. 1, April, hlm. 40-51.

Miftahurrohmah, 2015, "Manajemen Keluarga Perempuan Single Parent: Telaah Gender Kehidupan Keluarga Tenaga Kerja Indonesia" ", dalam Palastren: Jurnal Studi Gender Vol. 8, No. 1, Juni, hlm. 125-144.

Mokhzani, Azizah, 2000, "Penulisan Biografi Tan Sri Fatimah Hashim" dalam Sejarah Lisan di Asia Tenggara: Teori dan Metode. Jakarta: LP3ES

Mufthi, MF, 2010, “Dari Batu sampai Ponsel". Dalam http:// historia.id/ retro/dari-batu-sampai-ponsel. 30 November 2010. Diakses 30 Mei 2017.

,2015, "Kisah Pinah, Babu Bumiputra yang Bikin Belanda Gempar". Dalam Http://historia.id/mondial/kisahpinah-babu-bumiputra-yang-bikin -belanda-gempar. Diakses 30 Mei 2017.

Nugraha, Pepih, 2013, Menulis Sosok secara Insiratif, Menarik, Unik. Jakarta: Penerbit Buku Kompas.

Ong, Walter J. 2013, Orality and Literacy. Terjemahan oleh Rika Iffati. Kelisanan dan Keaksaraan. Yogyakarta: Gading Publishing.

Purbani, Widyastuti, 2013. "Watak dan Perjuangan Perempuan dalam Novel-Novel Karya Penulis Perempuan Indonesia dan Malaysia Awal Abad 21", dalam Litera, Jurnal Penelitan Bahasa, Sastra, dan Pengajaraannya Vol. 12, No. 2, Oktober, hlm.367-380.

Purnamaningsih, Nining. 2011. “Analisis Faktor-Faktor yang Mempengaruhi Tenaga Kerja Wanita Bekerja di Luar Negeri (Studi Kasus di Kediri)". Dalam Jurnal Ilmiah Berkala Universitas Kadiri. Edisi Juni - September hlm. 13- 26.

Pusat Bahasa Departemen Pendidikan Nasional, 2008, Kamus 
Bahasa Indonesia. Jakarta: Pusat Bahasa Departemen Pendidikan Nasional.

Raap, Olivier Johannes, 2013, Pekerdja di Djawa Tempo Doeleoe. Yogyakarta: Galang Pustaka.

. 2015a, Kota di Djawa Tempo Doeloe. Jakarta: Kepustakaan Populer Gramedia.

.2015b, Soeka Doeka di Djawa Tempo Doeloe. Jakarta: Kepustakaan Populer Gramedia..

Santasombat, Yos, 2000, "Sejarah Lisan dan Potret diri: Mewawancarai Elite Thai". dalam Sejarah Lisan di Asia Tenggara: Teori dan Metode. Jakarta: LP3ES.

Santoso, 2010, "Model Konseling Keluarga untuk Mengembangkan Kesiapan Mental Calon Tenaga kerja Wanita (TKW) dan Keluarganya". Dalam Jurnal Sosial dan Budaya. Vol. 3, No. 2, Desember, hlm.1-17.

Sarup, Madan, 1989, An Introdctury Guide to Post-Strukturalism and Postmodernism. Athens: The University of Georgia Press.

Saryono, Djoko, 2009, “Sosok Perempuan Indonesia dalam NovelNovel Indonesia Modern", dalam Litera, Jurnal Penelitan Bahasa, Sastra, dan Pengajaraannya. Vol. 8, No. 1, April, hlm.11-32.

Subadi, Tjipto, 2010, “Tenaga Kerja Indonesia di Malaysia (Studi Kasus TKW Asal Jawa Tengan dengan Pendekatan Fenomenologi)". Dalam Forum Geografi. 24 (2) Desember hlm 155-172.

Swingewood, Alan. and Laurenson, Diana. 1972, The Sociology of Literature. London: Paladin.

Wellek, Rene dan Austin Warren., 1990, Teori Kesusastraan. Terjemahan Melani Budianta. Jakarta: Gramedia.

Werdiningsih, Yuli Kurniati, 2016, "Kekerasan terhadap Tokoh Utama Perempuan dalam Novel Kinanti Karya Margareth Widhi Pratiwi", dalam Atavisme. Vol. 19, No. 1, Oktober, hlm.102-115. 
Wilkes, Chris, 2005, "Kelas Menurut Bourdieu" dalam Harker, Richard. Cheelen Mahar dan Chris Wilkes. Tt. in (Habitus $x$ Modal + ranah $=$ Praktik . Terjemahan by Pipit Maizier. Jogyakarta: Jalasutra.

Widyastuti, Sri Harti, 2014, "Kepribadian Wanita Jawa dalam Serat Suluk Residriya dan Serat Wulang Putri Karya Paku Buwono IX", dalam Litera, Jurnal Penelitan Bahasa, Sastra, dan Pengajaraannya. Vol. 13, No. 1, April, hlm.114-127.

Wiyatmi, 2012, "Dekonstruksi Sistem Patriarki dan Pencarian Identitas Novelis Perempuan Indonesia Tahun 2000-an", dalam Bahasa dan Seni. vol. 40, No. 1, Oktober, hlm.4554 . 